\title{
МЕДІАДОСЛІДЖЕННЯ
}

\author{
Visn. Lviv. Univ., Ser. Zhurn. 2020: 47; 224-237 • DOI: http://dx.doi.org/10.30970/vjo.2020.47.10521
}

УДК 14:323.14(470+571)"18"П.Чаадаєв

\section{ГЛОБАЛІЗМ ДУМКИ І ЧИНУ П. Я. ЧААДАСВА, АБО ПРО РОСІЙСБКИЙ НАЦІОНАЛ-ШОВІНІЗМ, А НЕ ЦИВІЛІЗАЦІЙНИЙ ЄВРОПОЦЕНТРИЗМ}

\author{
Мар'ян Житарюк \\ Львівський національний університет імені Івана Франка \\ вул. Генерала Чупринки, 49, 79044, Львів, Украйна \\ e-mail: mgzhyt@i.ua \\ https://orcid.org/0000-0002-5690-5701
}

У статті професора М. Житарюка акцентовано на актуальності філософічності думок і поглядів Петра Чаадаєва про російський імперіалізм (відсталість, реакційність), російське православ'я (політичний інструмент), російську культуру (вторинність супроти першоджерел). Йдеться про те, що вади XIX ст. реанімовано у XXI ст. Без осмислення помилок історії, в т. ч. світоглядних та морально-етичних, через мас-медіа, не збудуєш щасливе майбутнє.

Ключові слова: Петро Чаадаєв, «Філософічні листи», націонал-шовінізм, європоцентризм, публіцистика, глобалізм.

1. Постановка проблеми. У одному з листів до Фрідріха Вільгельма Шеллінга ${ }^{1}$ Петро Чаадаєв, захоплюючись поєднанням філософії одкровення й релігійної філософії, зізнався, що він загубився в розумових пустелях своєї країни і довго вважав, що тільки він один витрачає свої сили в цій праці або має тільки кількох товаришів, які розлетілися по землі. Потім він побачив, що увесь мислячий світ рухається в тому самому напрямку. «Великим став для мене той день, коли я зробив це відкриття»².

Сказати, що на П. Чаадаєва вплинули твори В. Шеллінга, - не сказати нічого. П. Чаадаєв зізнається, що вивчення творів німецького філософа відкрило йому новий світ: «завдяки вашому розуму в царстві думок мені прочинилися такі сфери, які досі були для мене цілком закриті; це вивчення стало для мене джерелом плідних і чарівних розмислів...»².

\footnotetext{
1 Чаадаев, П. (1832), Письма. Шеллингу, Москва, с. 2. URL: http://russianway.rhga.ru/upload/ main/21 Chaadaev2.pdf (дата перегляду 07 грудня 2019 р.). Переклад М. Житарюка.

2 Там само.

3 Там само.

(C) Житарюк М., 2020
} 
У такий спосіб Петро Якович Чаадаєв (1794-1856) і формувався як європеєць, який став непересічною постаттю в європейській історіософській думці першої половини XIX століття, твори якого й досі популярні в Західній Європі, хоч за життя царський режим визнав його божевільним (“через потребу”, - як напише згодом сам філософ та публіцист). П. Чаадаєв - не просто своєрідний камертон любові, християнства, гуманізму, який не визнає вищості однієї особи над іншою, бо від народження - всі рівні. П. Чаадаєв - також більмо на оці московщини, попівства й царату. Він не такий, як вони, він чужий для них. У прагненні зберегти інакшість, у нього не залишилось вибору, окрім як втекти з рідного пекла.

Путінська Росія - це намагання поєднати авторитарні химери й гримаси царату (XIX ст.), тоталітаризму й репресій більшовизму (XX ст.) і маніпулятивність та гібридність (XXI ст.). Це спроба зібрати в одне ціле уламки минулого, щоб з них сконструювати пародію майбутнього. Методи і засоби необмежені: брехня, шантаж, міфотворчість, використання нетрадиційної зброї (психотехніки, мас-медіа, інститут церкви).

Український філософ російського походження Микола Сергеєв (Львів) переконаний, що Росія може існувати тільки як імперія, а без України - вона не є повноцінною імперією, тому не має майбутнього як держава ${ }^{4}$.

Отже, Кремль завжди (коли агресивно, вульгарно, коли завуальовано, толерантно) намагатиметься «склеїти» відколені черепки і зшити розірване лахміття, він завше рухатиметься ніби вперед, озираючись на темне минуле, навіть якщо це призведе до остаточної руйнації - як самого себе, так і своїх сусідів. Тут як аргументи і «ядерна» кнопка, і вихід з чинних міжнародних угод, і намагання прищепити світу думку про збереження християнства... Але поки існуватиме РФ, доти існуватимуть інакомислячі, ті, що мають життєвий і моральний стрижень, послідовники П. Чаадаєва. Так само, доки існуватиме РФ, доти знаходитимуться національні зрадники, у т. ч. і з-поміж європейських правителів, які обиратимуть власну вигоду (газо- й нафтодолари), а не державну перспективу.

Актуальність изієї статті випливає із її мети - потреби переосмислення власної сутності на прикладі однієї особистості (П. Чаадаєва) й утвердження віри у здатність змінити ситуацію з негативу на позитив.

Головним своїм завданням вбачаємо донести до мислячих кіл думку про те, що, на цивілізаційному роздоріжжі, Росія, як і раніше (доба монголо-татарського іга), протистоятиме західній цивілізації, братиме участь у її знищенні, допомагаючи утвердити новий центр світу на чолі з Китаєм, який цю ж РФ і поглине.

2. Аналіз останніх досліджень та публікацій. Завдячуючи тому, що зараз інформаційна доба, текстів П. Чаадаєва і про П. Чаадаєва, попри деякі намагання контролювати й обмежувати до них доступ, сьогодні аж ніяк не бракує. С чимало й наукових спроб, як-от монографія 1908 р. Михайла Гершензона ${ }^{5}$, яку також варто переосмислити, багато критичних закидів (щодо нігілізму, невдячності П. Чаадаєва) $)^{6}, \epsilon$ деякі й наші напрацювання (переклад творів П. Чаадаєва українською, статті в

\footnotetext{
4 Сергеєв, Микола (2018), Власний архів: про Росію, Львів.

5 Гершензон, Михаил (1908), П. Я. Чаадаев. Жизнь и мышление, Санкт-Петербург, Типография М. М. Стасюлевича, 325 c. URL: https://imwerden.de/publ-2493.html (https://imwerden.de/pdf/ gershenzon chaadaev 1908.pdf)

6 Їх абсолютна більшість, т. зв. античаадаєвський лютий треш.
} 
журналі «Нова філологія», Запоріжжя, та у збірнику «Українська періодика: історія та сучасність», Львів, в авторському блозі «Теорії та моделі журналістики», виступ на презентації книги перекладів в Бібліотеці української літератури в Москві) 7 .

3. Методологічна основа дослідження охоплює осмислення текстів П. Чаадаєва, текстів про П. Чаадаєва та їх накладання на минуле, сучасне й майбутнє Європи. Йдеться про історичний аналіз, концептуальний аналіз, порівняння, метод ілюстрування.

\section{4. Виклад основного матеріалу дослідження.}

Твори родоначальника російської релігійної філософії П. Чаадаєва, які можна назвати сміливими спробами (чи не вперше!) об'єктивно осмислити російську історію та російську національну ідентичність, не пішли Росії на користь. Вони викликали в російській громаді небачене обурення, осуд, прокляття. Образи переважили Правду, гонор - не дозволив розмислювати над простими питаннями... Хто знає, можливо, якби в Російській імперії бодай трохи прислухались до голосів своїх пророків, світ ніколи не знав би Жовтневого перевороту 1917 року, а такі злі генії, як В. Ульянов (Лєнін), не писали б криваві сценарії переділу світу й не розбудовували б Росію, а згодом - СРСР, за утопією Платона («Закони»).

Так, П. Чаадаєв, можливо, був різким. Але хіба Правда завжди солодка і приємна? Ось уривки 3 першого філософічного листа: «Ми (росіяни. - М.Ж.) живемо лиш найобмеженішим сьогоденням, без минулого й майбутнього, серед мертвого застою», «...у нас немає нічого індивідуального, на що могла б опертись наша думка, але, відособлені дивною долею від всесвітнього руху людського, ми також нічого не сприйняли і зі спадкоємних ідей людського роду». Цьому теж $є$ пояснення: «Народи - настільки ж моральні, як і окремі особистості. Їх виховують віки, як окремих людей - роки. Але ми, можна сказати, - народ винятковий. Ми належимо до тих націй, які мовби поза родом людським, а існують лишень для того, щоб дати світові який-небудь важливий урок».

Чи почули П. Чаадаєва в Росії хоча б сьогодні? Без сумніву, ні. Інакше Кремль не розпочинав би того, що офіційні інформаційні рупори бездумно і з байдужою холодністю називали «антитерористичною операцією», «спецзачистками» тощо, ніби йшлося не про чеченський народ, не про матерів, дітей та старих, а, наприклад, про щось дуже буденне, як-от: «світить сонце» чи «йде дощ». Інакше В. Путін не пішов би на анексію українського Криму, не розв’язував би війну на українському Донбасі, у Сирії. Окремі інтелігентні кола - це виняток, це контреліта. Попри видання творів Чаадаєва і їхнє поширення в інтернеті, російський пророк у рідній вітчизні й далі чужий.

За життя П. Чаадаєва надруковано лише один твір - перший філософічний лист. Цю подію було висвітлено у журналі Надєждіна «Телескоп» (1836). Як наслідок - журнал закрито, редактора ув'язнено, а автора проголошено (не діагностовано!) божевільним. Твори енциклопедиста П. Чаадаєва, який об'їздив цілу Свропу, виходять переважно французькою, англійською, німецькою, проте вони заборонені в Росії. Лише напередодні Першої світової війни було видано двотомник «Сочинения

7 Докладніше подано у списку літератури.

8 Чаадаєв, П. (2005), Лист Перший, у кн.: П. Я. Чаадаєв. Філософічні листи. Апологія божевільного. Уривки та різні думки (1828-1850-ті роки), упорядник М. Житарюк, Львів, с. 6-20. 
и письма» (Т. 1-2. - 1913-1914). Та й за часів СРСР нам дозують правду, спотворюють уявлення про нього. Можна сказати, для широкого загалу П. Чаадаєв - постать майже невідома, навіть не всі гуманітарії до ладу можуть щось про нього сказати. А він заслуговує на визнання, осмислення, мабуть, не менше, ніж більшість загальновизнаних мислителів - від античних часів до сьогодення. I це - не високі слова. Щоб переконатись у глибокодумності, освіченості П. Чаадаєва, варто прочитати його твори, які - не данина часові, не замовлення академічної установи, не графоманство 3 метою заробити. Ні. Це - стан, порив душі, очищення сумління, i біль, і розпач, i надія, і віра, і любов. Його тексти народжені не хворобливою уявою, яку приписували сучасники, а глибоким аналізом (часто першоджерел) літературних, біблійних, культурно-мистецьких пам'яток давнини і свого часу - від грецької та римської антики, Китаю, Індії, Єгипту - до сучасної (початок XIX ст.) Європи та Росії.

\section{I}

Російський націонал-шовінізм відображає не тільки перманентний стан речей, a $є$ також синонімом до російського імперіалізму, комуністичної ідеології XX ст. чи великодержавного шовінізму. Актуальність проблеми посилюється не стільки звичайним нашим сусідством (хоч і цього було б досить, щоб про це говорити), а окресленням шляхів розвитку на величезних географічних просторах (майже шоста частина світу) понад сотні народів і народностей та їхнім впливом на загальносвітові процеси.

Цивілізаційний європоцентризм цікавить нас теж двояко. По-перше, хоч це і не панацея від усіх бід, проте російський мисленнєвий потенціал, максимально сконцентрований у творчості та діяльності П. Чаадаєва, розвинений і дещо спримітивізований та звульгаризований західниками, спромігся на інтелектуальний прорив i непопулярну, небезпечну для імперіалізму громадянську позицію. По-друге, в контексті без п'яти років двохсотліття від сформування платформи, цивілізаційний європоцентризм не тільки не перестав бути життєвою концепцією, а й постає перед російством і світом у значно ширшому, обнадійливішому контексті. Скористатися б цим шансом!

Постать П. Чаадаєва цікава для нас, українських дослідників публіцистики, не тільки тому, що він - досі не визнаний пророк своєї вітчизни - Росії, один із небагатьох чесних високоосвічених християнських філософів і публіцистів світового значення, дуже популярний сьогодні у прогресивних наукових колах, зокрема серед молоді. Принципово важливе інше - історична правда. Ця правда полягає в тому, що не тільки представники пригноблених російським імперіалізмом націй були спроможні (і спромоглись) на жертовність на благо націй (як, наприклад, Т. Шевченко), що не всі росіяни, які мають добру освіту і певне становище в суспільстві, навіть знайомі з царем, по-перше, шовіністи, по-друге, здатні на сумнівні угоди (так звані компроміси) із власною совістю та гідністю.

Визначальним моментом, таким собі лакмусовим папірцем усвідомлення національної шляхетності і готовності (здатності) зробити черговий, позитивний, крок для розбудови Росії, є справедливе і чесне ставлення (насамперед у науковому середовищі, потім - представниками влади і ламанням старих стереотипів серед громадськості з допомогою ЗМІ, художньої літератури, кінокультури тощо) до своїх, росій- 
ських умів, позбавлення їх численних тавр, у т. ч. й «божевілля». Як на мене, наївно сподіватись від кремлівських владоможців на чудо - адекватно оцінювати зміни у світі, насамперед, у слов'янському світі, і тим паче ставитись до них з повагою, допоки не буде поставлене й реалізоване просте і водночас дуже складне завдання - стати чесними бодай перед собою (як у минулому, так і в сьогоденні). Допоки не почуємо каяття за російських «божевільних», за злочини спочатку імперіалізму, а потім більшовизму (нищення націй, заборона інших, крім російської, мов, культур, традицій, спустошливі війни, голодомори-геноциди, репресії тощо), марно сподіватись від російського владної та науково-презентаційної еліти бодай якогось розвитку гуманізму, християнства, свобод і прав людей.

Відхід від прописаних ще 11 століття істин у «Слові про Закон і Благодать» Іларіона та «Повчанні дітям» Володимира Мономаха (у першому творі йдеться про Старий і Новий заповіти, про П'ятикнижжя Мойсеєве, яке віджило, бо базувалось на ненависті, і про Христову віру, основану на любові до ближнього; ближній - не тільки володар, а навіть бідняк, бо перед Господом усі рівні; Мономахова праця-пам'ятка - це кодекс середньовічного монарха) дозволяє припустити, що для правлячої Москви (Петербурга) ці писання завжди були чужими, недолугими, непристосованими, а часом непристойними. Парадокс, але політично витримані і кон'юнктурні гасла: «ми - брати-слов'яни», «Київська Русь - колиска трьох братніх народів» тощо стали домінантами історичного розвитку, навіть попри ігнорування глибинних думок Іларіона й Мономаха, попри спалення Батурина і знищення Запорозької Січі, попри великі переселення (українців на північ та схід, а росіян та інших, слухняніших, на південь (в Україну)...

Я схиляю голову перед усіма національними пророками в Російській імперії. Вони розуміли, що їхні вчинки переважно тотожні биттю голови об скелю, але за жодних обставин не втрачали віру. На відміну від правителів, які ніколи не знали, що таке Віра, що таке Надія, що таке Любов. I не хотіли знати. Тому й не розуміли жертовності, справжньої, не для слави. Я з тих, хто вважає, що Віра, помножена на діяльну Волю, здатна здолати найміцніші мури. Прикладів дуже багато - Т. Шевченко і Україна, Берлінська стіна, крах, здавалося б, вічних імперій... Водночас, я не такий ідеаліст, щоб стверджувати, буцімто Росія вже готова почути своїх пророків, змінитись і побачити світ по-новому, не з захмарної висоти, з точки зору націонал-шовінізму, а як рівний із рівним.

Отже, на мою думку, однією з таких лікувальних «пігулок» насамперед для Росії, а для нас це швидше приклад, може бути творча і життєва діяльність П. Чаадаєва.

Глобалізація давно стала об'єктивною реальністю, незважаючи на те, що не всі готові навіть зараз це визнати. Для одних ера глобалізації почалася з винаходом інтернету, для інших - 3 початком ери сателітарного телебачення, ще інші називають «початком кінця» створення кінематографа або електронних ЗМІ... Насправді ж це не зовсім так. Адже названі критерії ідентифікації поняття - це лише трансформаційно-цивілізаційні ознаки розвитку феномену, найвиразніші сегменти осучаснених форм, які, по-перше, стрімко розвиватимуться й надалі, по-друге, змінюватимуть світовий розвиток, по-трете, не оминуть нікого й ніде, незалежно від бажань, активних дій чи повного ігнорування окремих людей, етнічно-культурних груп, націй та континентів. 
Я з тих, хто не завжди і не всім захоплюється через посилення глобалізаційного фактору, однак я не можу поділяти позицію тих, котрі вважають, начебто можна у якийсь спосіб «зберегти нейтралітет». Вже сама історія показала, що «зберегти нейтралітет» практично не вдалось жодній нації, хіба що деяким тубільцям чи сніговій людині. Винайдення письма, пісні, печерні написи (малюнки) - ніщо інше, а зародки глобалізації, так звана нульова або початкова стадія глобалізації. Звісно, не до кінця осмислена. Першою фазою глобалізащії я б назвав появу релігій, перших книг, написаних на стилеті чи пергаменті, наприклад, уставом, згодом - скорописом, i перших бібліотек. Не так важливо, який відсоток населення мав до цих творів доступ. Водночас царі-королі-імператори і частина їхньої свити були не просто грамотними, а й доволі освіченими людьми, які не тільки читали, а й самі писали - і в такий спосіб впливали не тільки на своїх сусідів-лідерів, а навіть на інші народи. Якщо це не допомагало, закріплювали свої дії численними війнами, водночас творячи культурні інтервенції за допомогою сили, насилля, грабунку... Друга фаза глобалізації - винайдення, з одного боку, гусячого пера, з іншого - друкарського верстату. Третя фаза - поява газет і журналів. Четверта - винайдення радіо, n’ята - кінематографа, шоста - телебачення, ядерної зброї, сьома - супутникового телебачення, восьма інтернету... Зрозуміло, що нумерація тут радше символічна. Це ж стосується і характеристик.

Умовно кажучи, розвиток планети має свої фази розвитку, як і будь-якого живого організму. Нині стверджувати свою непричетність до глобалізації, це те саме, що відмовлятись од власної руки або голови, себто доводити щось неймовірне на кшталт: ноги самі по собі і не залежать від думок, продукованих головою. Навіть найбільші заперечувачі глобалізації ніяк не доведуть власного офсайду, адже не відмовляються від читання книжок, написання статей (чи пером-ручкою, чи на комп'ютері), оприлюднення власної позиції, не проміняють власне помешкання, обладнане радіо і телебаченням, на скитське існування, без надлишку, попри екологічну катастрофу і вичерпність традиційних видів енергоресурсів не відмовляться від пересування в авто(бусах), поїздами, кораблями, літаками, - на зміну газові й нафті невдовзі прийдуть термоядерні капсули, екологічно безпечніші та економічно доцільніші, що здешевлюватимуть енергоресурси майбутнього, порівняно з традиційними, у десятки, сотні разів. Тобто нині вже очевидно, що людина не здатна зупинитись на досягнутому і вдовольнитись існуючим. Людині завжди мало, вона завжди жадібна й незадоволена. Зрештою, це можна назвати агонією цивілізації. На жаль, це - теж факт, який, завдяки багатотисячолітній історії, вже незворотній, хоч до повного кінця можуть пройти ще десятки тисяч років. Як і людині, яка проходить свій земний шлях (цикл) розвитку - від народження до відходу в інші форми, так і планеті Земля цей шлях призначено. Який він - багато в чому залежить саме від людини.

Отже, підтверджую свою думку: ми всі в системі світової глобалізації. Заперечувати це - не розуміти людського покликання, не бажати долучитись до створення глобалізаційного позитиву, який унеможливив би принаймні на певний час тотальне самознищення.

Боги були першими, хто своїм прикладом, навіть через самопожертву, показав справжнє покликання людини - не кажу «людини розумної», маю на увазі «людину живу», діяльну. Далі були пророки, апостоли, святі, священнослужителі, окремі 
громадяни. Нині, у світі максимально інтенсифікованому та прискореному, надзвичайно збайдужілому та релятивізованому, тобто безпринципному, великою мірою обов'язки сіячів діяльності, творців позитиву мають виконувати і журналісти, які не тільки мають себе відокремити від усього довкола, мовляв, «ми тільки ретранслятори» - чужих слів, думок, вчинків, а й мають бути творцями, генераторами філософії любові, домінування життя. Себто мають взяти на себе обов’язки сучасних апостолів правди, хоч як важко це не було б. Щойно матимемо такі добрі паростки, можна буде трохи зітхнути. Бо це означатиме, що народжується Нова Людина, яка не протиставлятиме себе всім, а об'єднуватиме всіх довкола себе, що не задкуватиме і не ховатиметься від інших, а відкрито, щиро і жертовно творитиме для інших, тобто змінюватиме усе негативне, що назбиралось у глобалізаційному процесі за тисячоліття, на позитивне, тобто людина як мізерна, крихітна істота матиме унікальний шанс позбавитись власних численних недуг (не стільки фізичних, скільки моральних) і вилікувати, себто відродити щасливе життя (не те, що нині, коли всі довкола плачуть - від голоду, воєн, терору) на Землі.

Розумію, що ці думки можуть бути не надто популярні, дуже несподівані, навіть шокуючі. Розумію, що, можливо, не всі готові їх прийняти і схвалити - я не прагну цього. Значно важливіше, бодай на цьому етапі, - дати поживу для розмислу, ніж стверджувати істину. Істину не знає ніхто.

Працюючи над текстами П. Чаадаєва, довгий час ігнорованого на його батьківщині - Росії, неправильно трактованого в тоталітарну добу СРСР, мимоволі ловиш себе на думці: наскільки сучасним, містким, позитивним з точки зору глобалізації було, $є$ і буде його Слово. Ця людина або зарано (на кількасотліт), або запізно (аналогічно) народилась, бо сучасники його або ще, або вже не могли зрозуміти. I досі, як на мене, нащадки П. Чаадаєва не готові адекватно сприйняти написане в першій половині 19 ст. Якщо це було б не так, Росія не мала б таких царів (з «тупим виглядом», «олов'яними очима» - Чаадаєв про Олександра II), не допустила б панування «геніальних» тиранів (Леніна, Сталіна), та й зараз заслуговувала б не на самозакоханого і мізерного правителя (та й узагалі не на правителя), що не приховує (часом хизується ними) власних маніакальних комплексів...

Уже нині можна стверджувати, що російська наукова думка у сфері філософії, публіцистики, політології не матиме значного розвитку без переоцінки та осмислення своїх видатних «божевільних», представників антиімперського дискурсу, принаймні починаючи з 19 ст., з П. Чаадаєва.

У всіх своїх творах (чи то написаних у Росії, чи то за кордоном, зокрема у Франції) П. Чаадаєв постає вірним сином своєї землі, справжнім патріотом, схвильованим і небайдужим, інтелектуалом і християнином, людиною самовідданою у своїй праці та любові до інших (незалежно від віри і країни) і безкомпромісною до брехні, словоблуддя, псевдоосвіченості... П. Чаадаєв не визнає фальшивих авторитетів, він незламний у своїй вірі та переконаннях, хоч готовий до самопожертви задля істини i справедливості, задля передачі «зерен» правди і науки. П. Чаадаєв своїм життям i вчинками відкидає релятивне, хоч і Шекспірове, - «підпорядковуйся навіть собаці, коли вона при виконанні службових обов'язків», йому значно ближче Сковородин- 
ське - «найдобріша людина тим неспокійніша і нещасніша, чим більшу посаду вона займає, але для неї не народжена».

Як і Г. Сковорода, якого називали українським Езопом, Сократом, Горацієм, П. Чаадаєв вважає, що не все отрута, що неприємне на смак. У «Філософських листах», під час своєрідної переписки з Катериною Паніною, освіченою та небайдужою молодою особою, яка «не заглядала в Свангеліє» і «не ходила до церкви», оголюючи загальнолюдські і конкретно російські проблеми віри, культури, мистецтва, історії тощо і прагнучи донести до її серця власні відчуття і знання («не отруту, хоч і неприємну», а правду, щоб виправити ситуацію), Петро Якович натикається на грізну скелю - холодну й непоступливу, черству і байдужу, войовничу і безкомпромісну. Звісно, після публікації першого і єдиного філософського листа ніщо не могло порятувати його від царської люті Олександра II.

Хоч наш герой і не цитує Сковороду, все ж своїм характером він дуже схожий на великого Українця. Щоправда, Сковорода живе і творить у 18 ст., а Чаадаєв - у 19 ст., різні царі (там - цариця, а тут - цар), але імперіалізм однаково неприємний на запах, дотик, вигляд. Він - нестерпний. Для російських цариць Сковорода - це тільки непоганий співак у придворному хорі, але погана людина, яка відмовилась від життя в палацах, «не оцінила доброти», а Чаадаєв - навіть не співак, а нахабний вульгаризатор «його пресвітлості».

«Апологія божевільного» (1837, опубліковано лише по смерті в Парижі зусиллями князя Гагаріна) - певне пом'якшення тональності, виголошення жалю стосовно того, що його не зрозуміли, звинуватили, зробили хворим, а більше - що не сприймали серйозно. Це - певний розпач не через те, що його розуміння християнства, історії спотворене, а через те, що від початку дискусії справа не зрушила з мертвої точки, що губиться час... Так, тут теж глибинне Сковородинське - «більше думай і тоді вирішуй!».

Публіцистика П. Чаадаєва - це не тільки розвідки на актуальні теми (як, наприклад, «Декілька слів про польське питання», де чимало тез витримано у стилі слов'янофільства), а й оцінка та аналіз розвитку й надбань цивілізації, місця Росії у світі, гірка, але об'єктивна правда («Про культуру», «Філософські листи» - 3 погляду західництва), яка багато в чому збігатиметься з тезами пізнішої праці М. Костомарова «Дві руські народності», опублікованої у петербурзькому журналі «Основа».

Попри всю значущість, планетарність мислення (звісно, були в П. Чаадаєва і слабкі місця, насамперед позитивна оцінка значення Петра Першого), ні громадськість, ні культурно-мистецький світ, ні влада не прагнули прислухатись і тим паче визнати слушність голосу, волаючого в пустелі. Для перших і других таке визнання означало б, по-перше, зайняти позицію переслідуваних і непопулярних, по-друге, визнати власну слабкість, для влади ж це був би початок кінця. Отже, ніщо інше тільки егоїзм та пиха стають на заваді зародженню і розвитку російської державності не за імперською, а європейською моделлю, запропонованою П. Чаадаєвим ще 190 років тому. Натомість глобалізаційні процеси у світі через російський чинник, один з надпотужних на той час, розвиваються й інтенсифікуються зі знаком «мінус», себто як суцільний негатив.

Звісно, що пізніше, у XX ст., Росія посилила свій імперіалізм через більшовицький тоталітаризм, а всі сателітні народи не могли визволитись до розвалу СРСР не тільки через ігнорування П. Чаадаєва (деякий виняток - 1913-1914 рр., коли все-таки 
побачив світ двотомник «Сочинения и письма»), через відкидання позитиву глобалізації, запропонованого так давно у вигляді цивілізаційного європоцентризму.

Крім Чаадаєва, були й інші особистості, так звані пункти, рятівні соломинки, відліку розвитку за іншою моделлю. Але імперросійство більше було готове до того, що потім призвело до Жовтневого перевороту, в радянській історії відомого як Велика жовтнева соцреволюція, до пошуків і продовження себе у вигляді нового, ще централізованішого, мілітаризованішого й агресивнішого полідержавного утворення, своєрідного спрута - СРСР. Водночас великоросійський шовінізм (націонал-шовінізм) не щезає, він трансформується, адаптується і навіть зміцнюється. У цьому велика загроза для цивілізованого світу, для світу християнського, європейського, базованого на європейських традиціях, загалом європоцентричного, відкритого і незахищеного (як за часів Гітлера). Оскільки новітня російська «демократія» в особі своїх керманичів обирає шлях «мочіть в сортірє», «дєлать зачісткі», «ліквідіровать бандформірованія» тощо, то, звісно, для білокам'яної думки, щирість і розпач одного зі своїх визначних пророків і речників антиімперіалізму, того, хто задля іншого, позитивного і духовно-морального шляху розвитку вітчизни не зважав на себе, на жаль, і далі залишається «божевільним» розпачем, слабкістю, бо сила, вочевидь, це невичерпні природні багатства і ядерна зброя.

Звісно, про проблеми глобалізації і ㄲï розуміння, про завдання журналістики майбутнього можна було б написати цілу книжку.

Для повнішої аргументації власної позиції (не наполягаю, що правильної) подаю деякі цитати П. Чаадаєва, наче кров’ю писані, з його єдиної прижиттєвої публікації в Російській імперії («Філософські листи. Лист 1»)9:

«Ми ж (росіяни. - М.Ж.), прийшовши у світ, як незаконні діти, без спадку, без зв'язку з людьми, шчо жили на Землі до нас, ми не маємо у своїх сериях нічого з тих уроків, які передували нашому існуванню. Кожному з нас доводиться самому зв'язувати порвану нитку спорідненості. Що в інших народів є звичкою, інстинктом, ие нам доводиться вбивати в голови ударами молота. Намі спогади не виходять за вчорашній день; ми, так би мовити, дивні (кумедні) самі для себе. Ми так дивно мандруємо у часі, щзо з кожним нашим кроком вперед минула мить щзезає для нас назавжди. Це - закономірний спадок культури, щзо иілковито базується на запозиченні та наслідуванні. У нас зовсім немає внутрішнього розвитку, природного прогресу, кожна нова ідея безслідно витісняє старі, адже вона не є їхнім наслідком, а з'являється до нас Бог знає звідки. Оскільки ми сприймаємо завжди лише готові ідеї, то в нашому мозку не утворюються ті невиправні борони, які розвивалися б послідовно і які складали б їхню силу. Ми ростемо, та не дозріваємо; рухаємось вперед, та по кривій, тобто так, щуо не дійти до мети. Ми схожі на тих дітей, яких не привчили

\footnotetext{
9 «Філософські листи» написано з 1826 до 1830. Усього їх вісім, хоч раніше вважалось, що лише три, решту, мовляв, або не встиг написати, або вони не дійшли до нас. Обмежуємось цитуванням лише першого листа, бо, по-перше, і цього достатньо для осягнення глибини думки і розмислу, по-друге, щоб зекономити площу публікації. Процитовано за виданням: Чаадаєв, П. (2005), Лист Перший, у кн.: П. Я. Чаадаєв. Філософічні листи. Апологія божевільного. Уривки та різні думки (1828-1850-ті роки), упорядник М. Житарюк, Львів, с. 6-20.
} 
думати самостійно; у зрілому віиі в них немає нічого свого; усе їхнє знання - в їхньому зовнішньому побуті, вся їхня душа - поза ними. Саме такі ми».

«Історичний досвід для нас не існує, покоління і століття минули для нас марно. Дивлячись на нас, можна було б сказати, щзо загальний закон людства відмінено щзодо нас. Одинокі у світі, ми нічого не дали світові, нічого не навчили його; ми не запропонували жодної ідеї до чисельних ідей людських, нічим не сприяли прогресові людського розуму, і все, щңо отримали від иьвого прогресу, ми спотворили. 3 першої хвилини нашого суспільного існування ми нічого не зробили для загального блага людей; жодна корисна думка не народилась на безплідному трунті нашої батьківщини; жодна велика істина не вийтла з нашого середовищц; ми не утруднювали себе щьось придумати самі, а з того, щзо вигадали інші, ми переймали тільки оманливу зовнішність і даремну розкіш».

«Якщео б дикі орди, щุо обурили світ, не пройшли по краӥні, в якій живемо, перед тим, як прямувати на Захід, нам ледве була б відведена сторінка у всесвітній історії. Якщо б ми не розкинулись від Берінгової протоки до Одера, нас і не помітили б...» «Хоч ми й називались християнами, плід християнства для нас не дозрівав...»

«Уся історія найновітнішого суспільства (про Європу. - М.Ж.) здійснюється на трунті думок. Таким чином, вона і є справжнім вихованням. Утверджене спочатку на иій основі, суспільство розвивалось лите з допомогою думки. Інтереси завжди були після ідей, а не перед ними. Переконання ніколи не випливали там з інтересів, а завжди інтереси породжувались переконаннями».

III

Чи була б актуальною проблема російського націонал-шовінізму, за інших, не авторитарних, а гуманістичних та християнських цінностей, які, на жаль, нині більш віддалені у РФ, ніж в роки перебудови в СРСР? Мабуть, що так, але не стояло б питання настільки гостро, якби не було кривавих подій у Прибалтиці у січні 1990 р., Карабаського, Придністровського конфліктів, Першої і Другої російсько-чеченської воєн, анексії Криму, окупації Донбасу, війни в Сирії тощо. Змушений констатувати, що визволення з радянської імперії Росії і набуття нею самостійності не тільки не гарантувало переосмислення себе як колонії, а й посилило б внутрішню реакцію федерації щодо інших націй. Звісно, що за таких обставин П. Чаадаєв, А. Мєнь, Г. Новодворська, Г. Політковська (Мазепа), Б. Нємцов та інші залишатимуться проблемними постатями для утвердження автократизму як перехідної форми існування та збереження тоталітаризму.

На прості запитання («Чи потрібна Росії така “демократія”?», «Чи хочуть росіяни такої Росії?», «Чи потрібна світові така Росія?») відповідей чимало, різних. Якщо невизначеність (брак сміливості чи позиції) самих росіян більше дивує, ніж обурює, то релятивістська позиція світу - від найближчих сусідів до Заходу чи Сходу - незрозуміла навіть для російських прогресивних кіл. Адже налагодження утопічної моделі в окремій країні, утвердження безкарності спонукатиме до їі поширення на інших, набагато ширших, просторах (це вже робили і Гітлер, і Сталін). Ніхто не гарантує недоторканість Євросоюзу в майбутньому, як і те, що НАТО існуватиме вічно. Як і будь-який союз, утворений штучно, не на національній основі, ЄС приречений рано чи пізно розпастись (хіба можна було собі уявити, в який спосіб зникне 
СРСР?) - ось де справжній клондайк для поширення російського (можливо, у спілці з китайським) автократизму, зміцнюваного щораз сильніше націонал-шовінізмом!

У контексті формування геополітичної карти на межі тисячоліть пригадую геноцид, голокост щодо українства у $1932-1933$ pp. ${ }^{10}$, донедавна не трактований справедливо навіть в Україні - щоб не образити євреїв та росіян. Насправді ж не має значення національність злочинців (серед них було чимало й українців), потрібно засудити, дати об’єктивну оцінку системі, більшовицькому тоталітаризму.

Західна цивілізація вабить нас культурними традиціями, свободами і правами, ціннісними орієнтирами, проте вона прогнила через самолюбство, надситість, зарозумілість, втратила форму, не продукує нових ідей... Якби бодай одну європейську націю спіткало те, що Україну (йдеться не тільки про XX ст., ні! Йдеться про час, коли Ф. Прокопович поміняв Україну на Росію, наче хатні капці), ця країна навряд чи вижила б і чи відродилася б, як фенікс. Невідомо, чи було б ЄС, чи загравали б європейці в любов до росіян. Але зараз важливе не це.

Чому, на мою думку, все ж потрібно самій Росії змінити вектори розвитку з великодержавного шовінізму, який начебто її зміцнює, а насправді руйнує, на цивілізаційний європоцентризм, на життя на християнських засадах? Відповідь проста: Україна нарешті спромоглась на самостійність у виборі стратегічних і культурних шляхів розвитку, Україна не входитиме в Свропу прохаючи (хоч часом це так і виглядатиме), а повертатиме собі Європу, бо саме Європа була іï органічним середовищем задовго до виникнення Росії і появи останньої на будь-яких мапах. Справжня, перспективна, цивілізована й гармонійна Росія неможлива без України ніколи. Князівські міжусобиці й напади орд зі сходу, тотальні асиміляції зміцнили майбутню Росію, прищепили імунітет на витривалість і живучість, але ж і закодували ненависть, агресію, самоліквідацію. Росію завжди рятувала-живила Україна, навіть козаками-петроградобудівниками, багатомільйонними в'язнями, чарівними жінками...

Чаадаєв не давав оцінки Україні і не осмислював їі значення (принаймні письмово), але, критично ставлячись до історії Росії, просто волав про європейський вектор розвитку Росії як єдино правильний, безальтернативний, бо це шлях, на який треба стати якнайшвидше. Як відомо, за висловлення власної позиції, його оголосили «божевільним» і заборонили публікувати. Чаадаєв був непопулярний на батьківщині протягом усього часу від оприлюднення першого філософського листа.

Чи почує Росія свого мислителя, письменника, публіциста («Інтереси завжди були після ідей») бодай зараз, і чи спроможеться вона нарешті змінитись, відійти від націонал-шовінізму - питання все ще відкриті, хоч і більше риторичні, але від цього не менш актуальні ні для української, ні для європейської, ні тим паче для російської публіцистики.

Тут важко не погодитися з О. Пахльовською, чиї концептуально-образні спостереження допомагають зрозуміти: суть справи в іншій, не владно-політичній, а світоглядно-орієнтаційній площині: «Саме в Києві, серці гіпотетичного «слов'янського братства», розділені міліцейським кордоном, на майдані Незалежності та на Європейській площі стоять один проти одного два некомунікабельні світи. Дві не-

10 Житарюк, М. (1997), Московська режисура голокосту: слов'янська любов чи азійська ненависть? Трактування проблеми в українській та закордонній журналістиці довоєнного періоду: історико-публіцистичний аспект: наукова брошура, Львів, За вільну Україну, 56 с. 
примиренні цивілізації. Саме в Україні схід наступає на захід. Саме в Україні виявляється їхня цілковита нездатність не лише до співіснування та співпраці, а просто до елементарного прагматичного діалогу. Саме в Україні Росія остаточно доводить, що вона не є Європою. Не збирається нею бути. I не відчуває в цьому жодної потреби» ${ }^{11}$.

5. Результати і перспективи подальших досліджень. Концептуальна публіцистика П. Чаадаєва завжди матиме попит. Її можна вивчати окремо, можна в контексті сучасників, можна крізь майбутню візію - і як аргументацію, і як ілюстрацію, і як смислоконструювання. Тому доречно перечитувати П. Чаадаєва, використовувати його тексти для формування хрестоматійної бази з зарубіжної публіцистики та навчання журналістів.

6. Висновок. Вважаю, варто якнайшвидше і якнайширше актуалізувати мисленнєву журналістику, несправедливо витіснену примітивно-бездумним репортерством і комп'ютерним клонуванням, повсюдно трактованими як панацея. У світлі останніх десятиліть ми остаточно переконались у тому, що одне з найважливіших покликань справжньої журналістики (і це давно пора нарешті взяти за правило у повсякденні) - не висвітлювати (переказувати прес-конференції, релізи, виступи), не оцінювати (з погляду пропагування зла або спецтехнологій «чорних» паблік рілейшн3), не розважатись (танцювати на цвинтарі), а змінювати людину, робити її кращою, милосерднішою, освіченішою. Як на мене, нині це - щось важливіше за просто слова, вочевидь, це - потреба: самоусвідомлення, становлення і розвитку національного журналізму.

Першочерговим, як на мене, залишається не питання надуманості/ реальності глобалізму як явища виключно «кінця 20 - початку 21 століття», а переродження людини i, відповідно, їі спонукально-дієве одухотворення - творити добро, радіти життю, любити світ... Тільки-но таку життєву платформу серйозно сприйме, за основу, не на кпини більшість людей, з'явиться надія на глобалізаційні процеси зі знаком «плюс». Шлях непростий, але реальний.

Стосовно ж сфери журналістики, то тут закони ті самі. I коли розмови про одухотворення людини, про пробудження людського в людині, ініційовані багатьма людинолюбцями і на різних континентах, і пропаговані в нас, перестануть дратувати чи навіть виводити з себе наших колег-журналістів та їхніх власників, можна буде сказати дві речі: по-перше, нарешті ми (і людство) маємо шанс перестати залишатись залежними від глобалізації, оскільки глобалізація залежатиме від нас, а ми її творитимемо зі знаком «плюс»; по-друге, ми, науковці-журналістикознавці, працювали недарма...

Нині ж про все це говоримо в контексті нереалізованих, але ще не втрачених можливостей - «contra spem spero!».

\section{СПИСОК ЛІТЕРАТУРИ}

1. Гершензон, Михаил (1908), П. Я. Чаадаев. Жизнь и мышление, Санкт-Петербург, Типография М. М. Стасюлевича, 325 с. URL: https://imwerden.de/publ-2493.html (https://imwerden.de/pdf/gershenzon_chaadaev_1908.pdf)

\footnotetext{
${ }^{11}$ Пахльовська, Оксана (2007), «Росія - не Європа», Post-Постуn, Львів, № 8 (14), с. 28.
} 
2. Житарюк, Мар'ян. (1997), Московська режисура голокосту: слов'янська любов чи азійська ненависть? Трактування проблеми в українській та закордонній журналістиці довоєнного періоду: історико-публіцистичний аспект: наукова брошура, Львів, За вільну Україну, 56 с.

3. Житарюк, Мар'ян. (2005), «Публіцистика П. Чаадаєва як різновид глобалізаційного позитиву», Нова філологія, Запоріжжя, №3 (23), с. 94-102.

4. Житарюк, Мар'ян. (2005), «Російський націонал-шовінізм чи цивілізаційний європоцентризм?», Збірник пращьь Науково-дослідного цеентру періодики, Вип. 13, Львів, с. 457-465.

5. Житарюк, Мар'ян. (2006), Виступ на презентації книги перекладів П. Я. Чаадаєва українською мовою в Бібліотеці української літератури в Москві (10-11 листопада 2006 p.). URL: http://mgzhyt1.blogspot.com/2014/01/blog-post_19.html

6. Пахльовська, Оксана (2007), «Росія - не Європа», Post-Постуn, Львів, № 8 (14), c. 28 .

7. Сергеєв, Микола (2018), Власний архів: про Росію, Львів.

8. Сергеєв, Микола (2018), Русь і Залісся: національна ідея як чинник державотворення, Львів, Ліга-Прес, 300 с.

9. Чаадаев, Петр. (1832), Письма. Шеллингу, Москва, с. 2. URL: http://russianway. rhga.ru/upload/main/21 Chaadaev2.pdf (дата перегляду 07 грудня 2019 p.).

10. Чаадаєв, Петро. (2005), Лист Першици, у кн.: П. Я. Чаадаєв. Філософічні листи. Апологія божевільного. Уривки та різні думки (1828-1850-ті роки), упорядник М. Житарюк, переклад з російської - М. Г. Житарюк, В. А. Житарюк, Львів, с. 6-20. ISBN 5-8326-0145-9. URL: http://old.journ.lnu.edu.ua/kaf zp/Books/Zhytariuk.\%20Chaadaev_Book.pdf

\section{REFERENCES}

1. Gershenzon, Mikhail (1908), P. Ya. Chaadayev. Zhizn i myshleniye. Sankt-Peterburg, Tipografiya M. M. Stasyulevicha, 325 s. URL: https://imwerden.de/publ-2493.html (https://imwerden.de/pdf/gershenzon chaadaev 1908.pdf)

2. Zhytariuk, Marian. (1997), Moskovska rezhysura holokostu: slovianska liubov chy aziiska nenavyst? Traktuvannia problemy v ukrainskii ta zakordonnii zhurnalistytsi dovoiennoho periodu: istoryko-publitsystychnyi aspekt: naukova broshura, Lviv, Za vilnu Ukrainu, $56 \mathrm{~s}$.

3. Zhytariuk, Marian. (2005), «Publitsystyka P. Chaadaieva yak riznovyd hlobalizatsiinoho pozytyvu», Nova filolohiia, Zaporizhzhia, №3 (23), s. 94-102.

4. Zhytariuk, Marian. (2005), «Rosiiskyi natsional-shovinizm chy tsyvilizatsiinyi yevropotsentryzm?», Zbirnyk prats Naukovo-doslidnoho tsentru periodyky, Vyp. 13, Lviv, s. 457-465.

5. Zhytariuk, Marian. (2006), Vystup na prezentatsii knyhy perekladiv P. Ya. Chaadaieva ukrainskoiu movoiu v Bibliotetsi ukrainskoi literatury v Moskvi (10-11 lystopada 2006 r.). URL: http://mgzhytl.blogspot.com/2014/01/blog-post 19.html

6. Pakhlovska, Oksana (2007), «Rosiia - ne Yevropa», Post-Postup, Lviv, № 8 (14), s. 28.

7. Serheiev, Mykola (2018), Vlasnyi arkhiv: pro Rosiiu, Lviv.

8. Serheiev, Mykola (2018), Rus i Zalissia: natsionalna ideia yak chynnyk derzhavotvorennia, Lviv, Liha-Pres, $300 \mathrm{~s}$. 
9. Chaadaev, Petr. (1832), Pysma. Shellynhu, Moskva, s. 2. URL: http://russianway.rhga. ru/upload/main/21 Chaadaev2.pdf (data perehliadu 07 hrudnia 2019 r.).

10. Chaadaiev, Petro. (2005), Lyst Pershyi, u kn.: P. Ya. Chaadaiev. Filosofichni lysty. Apolohiia bozhevilnoho. Uryvky ta rizni dumky (1828-1850-ti roky), uporiadnyk M. Zhytariuk, pereklad z rosiiskoi - M. H. Zhytariuk, V. A. Zhytariuk, Lviv, s. 6-20. ISBN 5-8326-0145-9. URL: http://old.journ.lnu.edu.ua/kaf zp/Books/Zhytariuk.\%20 Chaadaev Book.pdf

\title{
GLOBALISM OF THOUGHT AND ORDER OF P. CHAADAEV, OR ABOUT RUSSIAN NATIONAL CHAUVINISM, NOT CIVILIZATIONAL EUROCENTRISM
}

\author{
Marian Zhytaryuk \\ Ivan Franko National University of Lviv, \\ Generala Chuprynky Str. 49, 79044, Lviv, Ukraine \\ e-mail:mgzhyt@i.ua \\ https://orcid.org/0000-0002-5690-5701
}

Professor M. Zhytaryuk's article focuses on the urgency of the philosophical thoughts and views of Petro Chaadaev about Russian imperialism (backwardness, reactionary character), Russian Orthodoxy (political instrument), Russian culture (minority about primary sources). It is said that defects of the nineteenth century are reanimated in the 21st century. It is impossible to create a happy future without comprehension of history mistakes, including outlook and moral and ethical ones.

The topicality of this article follows from its purpose - the need to rethink the own essence on the example of one person (P. Chaadaev) and to assert belief in the ability to change the situation from negative to positive.

The main author's task is to report to the thinking circles that, at civilizational crossroads, Russia will still (as in the Western Mongol-Tatar yoke time) resist Western civilization, will participate in its destruction, helping to establish a new center of the world, headed by China, what will engross the RF.

The author uses his previous works, including translation of writings by Petro Chaadaev from Russian into Ukrainian (together with his wife Victoria), articles in the journal "New Philology" (Zaporizhzhia) and in the collection of scientific works "Ukrainian Periodicals: History and Modernity" (Lviv), in the author's blog "Theories and Models of Journalism", a speech at the presentation of a book of translations at the Library of Ukrainian Literature in Moscow.

Results and prospects for further research. The conceptual journalism of P. Chaadaev will always be in demand. It can be studied individually or in the context of contemporaries. It can be studied through the future vision - both as argumentation, as illustration, and as meaningmaking. Therefore, it is appropriate to read P. Chaadaev, to use his texts to form a textbook base on foreign journalism and to train journalists.

Key words: Petro Chaadaev, Philosophical Letters, National Chauvinism, Eurocentrism, Publicism, Globalism. 